Relationship between carbon stocks and tree species diversity in a humid Guinean savanna landscape in northern Sierra Leone

\title{
Amara, Edward
}

2019-07-03

Amara , E , Heiskanen , J , Aynekulu , E \& Pellikka , P K E 2019 , ' Relationship between carbon stocks and tree species diversity in a humid Guinean savanna landscape in northern Sierra Leone ' , Southern Forests , vol. 81 , no. 3 , pp. 235-245 . https://doi.org/10.2989/20702620.2018.1555947

http://hdl.handle.net/10138/307230

https://doi.org/10.2989/20702620.2018.1555947

cc_by

acceptedVersion

Downloaded from Helda, University of Helsinki institutional repository.

This is an electronic reprint of the original article.

This reprint may differ from the original in pagination and typographic detail.

Please cite the original version. 
1 Relationship between carbon stocks and tree species diversity in a humid Guinean savannah landscape in Northern Sierra Leone

4 Edward Amara ${ }^{a, b, c, d *}$, Janne Heiskanen ${ }^{a, d}$, Ermias Aynekulu $^{b}$, Petri K. E. Pellikka ${ }^{a, d}$

5 a Earth Change Observation Laboratory, Department of Geosciences and

6 Geography, P. O. Box 68, FI-00014 University of Helsinki, Finland;

7 edward.amara@helsinki.fi, janne.heiskanen@helsinki.fi, petri.pellikka@helsinki.fi

b World Agroforestry Centre (ICRAF), United Nations Avenue, P. O. Box 30677

00100, Nairobi, Kenya; e.betemariam@cgiar.org

c Sierra Leone Agricultural Research Institute (SLARI), Tower Hills, PMB 1313,

11 Freetown, Sierra Leone

d Institute for Atmospheric and Earth System Research, Faculty of Science,

University of Helsinki, Finland

\section{*Corresponding author: edward.amara@helsinki.fi}

\section{Abstract}

17 Global sustainable development goals include reducing greenhouse gas emissions from land use change and maintaining biodiversity. Many studies have examined carbon stocks and tree species diversity, but few have studied the humid Guinean savannah ecosystem. This study focuses on a humid savannah landscape in Northern Sierra Leone, aiming to assess carbon stocks and tree species diversity and compare their relationships in different vegetation types. We surveyed 160 sample plots ( $0.1 \mathrm{ha})$ in the field for tree species, aboveground carbon (AGC) and soil organic carbon (SOC). In total, 90 tree species were identified in the field. Gmelina arborea, an exotic tree species common in the foothills of the Kuru Hills Forest Reserve, and Combretum 
glutinosum, Pterocarpus erinaceous and Terminaria glaucescens, typical savannah

27 trees, were the most common species. At landscape level, the mean AGC stock was 29.4 Mg C ha-1 (SD 21.3) and mean top-soil $(0-20 \mathrm{~cm})$ SOC stock was $42.2 \mathrm{Mg} \mathrm{C} \mathrm{ha-1}^{-1}$ (SD 20.6). Mean tree species richness and Shannon index per plot were 7 (SD 4) and 1.6 (SD 0.6), respectively. Forests and woodlands had significantly higher mean AGC and tree species richness than bushland, wooded grassland or cropland $(p<0.05)$. In the forest and bushland, a small number of large diameter trees covered a large share of the total AGC stocks. Furthermore, a moderate linear correlation was found between AGC and tree species richness $(r=0.475, p<0.001)$ and AGC and Shannon index $(r=0.375, p<0.05)$. The correlation between AGC and SOC was weak $(r=$ $0.17, p<0.05)$. The results emphasize the role of forests and woodlands and large diameter trees in retaining AGC stocks and tree species diversity in the savannah ecosystem.

Keywords: tree species; aboveground carbon; soil organic carbon 


\section{Introduction}

Savannahs are an important component of global vegetation as they cover more than $10 \%$ of the global land surface (Scholes and Walker 1993) and account for $30 \%$ of primary production of global terrestrial biomes (Grace et al. 2006). Global carbon stocks of forests are estimated to be $861 \pm 66 \mathrm{Pg} \mathrm{C}$, of which $44 \%$ is stored in soil, $42 \%$ in living biomass (aboveground and belowground) and the rest in deadwood and litter (Pan et al. 2011). Meanwhile, tropical savannah and grassland store $336 \mathrm{Pg} \mathrm{C}$ (Carvalhais et al. 2014), but soils contain at least as much carbon as stored in the biomass (Anderson 1991, Eswaran et al. 1993, Scholes and Hall 1996). This is because carbon in the aboveground pool tends to be more responsive to changes in disturbance regime (Higgins et al. 2007).

In addition to the carbon stocks, savannahs harbour a vast number of plant species and are important for global biodiversity (Abreu et al. 2017). These plant species support ecosystem functions (Abreu et al. 2017) and play a substantial role in the global carbon cycle (Majumdar et al. 2016). However, tree cover in the savannahs is affected by deforestation and degradation, leading to climate change and biodiversity loss (Strassburg et al. 2010, Thomas et al. 2004, Talbot 2010). Pellegrini et al. (2015) reported a large carbon-diversity trade-off between the maintenance of endemic savannah species and the promotion of carbon storage through woody plant cover. Finding such synergies between climate change mitigation and biodiversity conservation could be elementary for attaining goals 13 and 15 of the sustainable development goals. These include actions to combat climate change and land degradation and actions to halt biodiversity loss through sustainable forest management. 
In Africa, savannahs cover even ca 50\% of the terrestrial territory (Grace et al. 2006), which emphasize their role in the continental carbon cycle and biodiversity. However, despite their role to humans and potential for carbon storage, African savannahs remain rather poorly studied in comparison to other biomes (Jeltsch et al. 2017, Scholes and Archer 1997). African savannahs are distributed in Sahelian, Sudanese and Guinean zones (CILSS 2016). Part of the savannahs, such as the humid Guinean savannahs, have lost their original forest cover as a result of anthropogenic interference (CEPF 2000). The Guinean savannahs contain diverse forest habitats that provide refuges to numerous species, and the region is considered a global priority region for conservation because of the high endemism of flora and fauna (Bakarr et al. 2004). The humid Guinean savannah of Sierra Leone is an ecotone between the tropical rainforest and the Sudanese savannah characterized by high precipitation. The high annual precipitation in this biome enhances woody canopy closure, and disturbances (e.g. fire, grazing) are required for the coexistence of trees and grasses (Sankaran et al. 2005). Therefore, the biotic and abiotic drivers and processes play an important role in the current woody species distribution and composition as well as ecosystem functioning (Oliveras and Malhi 2016).

Information on carbon stocks by vegetation type is important for the implementation of Reducing emissions from deforestation and forest degradation (REDD+) but unfortunately, data on biomass and soil carbon stocks for Sierra Leone are poorly available. The database of UNEP-WCMC (2011) estimates the total terrestrial carbon stock of Sierra Leone to be $944 \mathrm{Mt}$, of which $519 \mathrm{Mt}$ is allocated in the soil and $425 \mathrm{Mt}$ in biomass. The distribution of the carbon stocks is uneven, with low carbon stocks in biomass but high soil carbon for more than $40 \%$ of the land (UNEP-WCMC 2011). Using remote-sensing methods, Bouvet et al. (2018) estimated AGC stock in Sierra 
Leone's savannah to be $276 \mathrm{Mt}$ C, which lies between the estimates based on Saatchi et al. (2011) and Avitabile et al. (2016), 346 Mt C and 215 Mt C, respectively. Therefore, more information is required, particularly on carbon stocks and biodiversity in the Sierra Leone's savannah region at the scale relevant for land management planning.

Many studies have examined the relationship between biodiversity (tree species diversity) and carbon stocks (biomass and soil), but the results are contradictory (Mensah et al. 2016a). Gamfeldt et al. (2015) and Dayamba et al. (2016) reported a positive relationship between the tree species diversity and multiple ecosystem services, such as biomass and soil carbon stocks, in different biomes. Filqisthi and Kaswanto (2017) and Zimudzi et al. (2016), on the other hand, reported no relationship between the tree species diversity and carbon stocks for pekarangan home gardens in West Java, Indonesia, and in Ngomakurira Mountain, Zimbabwe, respectively. Sharma et al. (2010) observed that forest types with higher tree species diversity had relatively low aboveground carbon (AGC) stocks in Garwal Himalaya, India. Furthermore, Kirby and Potvin (2007) and Saha et al. (2009) did not observe a clear relationship between soil organic carbon (SOC) stocks and tree species diversity in Eastern Panama and home gardens in Kerala, India, respectively. However, Chen (2006) reported a positive relationship for old growth forest in Changbai Mountain, China. While relationships between carbon stocks and biodiversity have been studied in various ecosystems and forest types, such results are not available for Sierra Leone's savannah region.

The objective of this study was to assess carbon stocks and tree species diversity and their relationships in a Guinean forest-savannah landscape in Northern Sierra Leone. More specifically, AGC, SOC and tree species composition, richness and diversity 
were inventoried and examined per vegetation type and stem diameter class.

115 Furthermore, the linear relationships between the different variables were studied by correlation analysis to examine if $\mathrm{AGC}$ and $\mathrm{SOC}$ are related to tree species diversity

117 in the study area.

\section{Materials and methods}

\subsection{Study area}

121 The study area is $100 \mathrm{~km}^{2}$ in Northern Sierra Leone (Fig. 1). The closest community 122 to the site was Sanya village. A part of the study area $\left(70 \mathrm{~km}^{2}\right)$ was in Kuru Hills Forest 123 Reserve (Fig. 2a, Fig. 2b). The climate is monsoon-type humid tropical with a unimodal raining season, lasting for about six months from May to October (Gomez Paloma and Acs 2012). According to Hijmans et al. (2005), annual mean rainfall is $2244 \mathrm{~mm}$ and monthly mean temperature ranges between $23^{\circ} \mathrm{C}$ and $29^{\circ} \mathrm{C}$. Topographically, the site is in the interior plateaus with low rolling hills. The elevations range from approximately $30 \mathrm{~m}$ a.sl. in the plateau to $700 \mathrm{~m}$ a.s.I. in Kuru Hills.

The main vegetation type in the landscape is tree savannahs of broad-leaved deciduous trees with a continuous ground cover of perennial bunch grasses and forbs (Fig. 2c). Some examples of common tree species are Pterocarpus erinaceus and Parkia biglobosa, and typical grasses include Andropogon gabonensis and Andropogon tectorum. The species composition varies per abiotic factors (moisture regime, soil type) and by the type and degree of disturbance (fire, anthropogenic, and grazing). During the rainy season, vegetation is green and covered with tall grasses that grow and reach maturity rapidly, thus becoming fibrous and tough. In the dry season, grasses tend to dry and disappear due to periodic bush-burning between 
138 November and April (Fig. 2d, Fig. 2f). Forests are moist with deciduous or semievergreen species and found on the banks of rivers or streams and in the protected area in Kuru Hills (Fig. 2a). The main livelihood in the region is agriculture, primarily slash-and-burn cultivation for food but also market gardening and agroforestry (Fig. 2e). Livestock farming and timber harvesting are also common (Sierra Leone scoping report for the Building biocarbon and rural development in West Africa project, 2014, unpublished). Non-timber forest products (mainly honey, fruits, medicine and hunting) provide additional support for inhabitants of the region.

\subsection{Sampling design}

Data collection took place between April and May 2014 using the land degradation surveillance framework (LDSF) sampling design (Vågen et al. 2013). LDSF is intended to provide a biophysical baseline at landscape level and a monitoring and evaluation framework for assessing processes of land degradation and the effectiveness of landscape rehabilitation measures over time. The sampling is built around a hierarchical field survey and sampling protocol using sites that are $100 \mathrm{~km}^{2}(10 \mathrm{~km} \times$ $10 \mathrm{~km}$ ) in size. The site comprised of sixteen 100 ha clusters (radius $564 \mathrm{~m}$ ) that consisted of ten sample plots each, making a total of 160 plots. Because of the stratified random sampling strategy, clusters were located both in the plateau and in the Kuru hills forest reserve (Fig. 1). The sample plots were circular in shape with 0.1 ha main plot (radius $17.84 \mathrm{~m}$ ) and four 0.01 ha sub-plots (radius $5.64 \mathrm{~m}$ ) (Fig. 3).

The sample plots were stratified into vegetation types for analysis according to White (1983) classification (Table 1) used in the LDSF survey (Vågen et al. 2013). Thickets 
and shrubland were incorporated into bushland and grassland into wooded grassland because those plots were very few and had similar characteristics.

\subsection{Inventory and tree diversity indices}

Trees with a diameter at breast height $(\mathrm{DBH})>10 \mathrm{~cm}$, including palms, were recorded in the main plot (0.1 ha) using calliper or diameter tape. Heights $(\mathrm{H})$ of sample trees with the largest, median and smallest DBH were also measured using a hypsometer or a measurement pole. Crown diameter in two directions (the widest width and perpendicular direction) of the sampled trees were measured using a measuring tape. Trees with DBH of $4-10 \mathrm{~cm}$ were counted in the sub-plots $(0.01 \mathrm{ha})$, and $\mathrm{DBH}, \mathrm{H}$ and crown diameter were measured for median DBH trees. Botanical names of the trees were based on Savill and Fox (1967), but some species (6.8\%) could not be identified. The two-parameter Curtis's function (Curtis 1967) and non-linear mixed-effects model with plot as random effects was used for H-DBH modelling (Valbuena et al. 2016). The model was used to predict $\mathrm{H}$ for all the trees with only $\mathrm{DBH}$ measured in the field. The modelling was carried out using 'nlme' package (Pinheiro et al. 2014) in R statistical software (R Core Team 2015).

The tree species diversity indices included species richness (S), defined as the total number of species present in the plot, and Shannon diversity index $\left(\mathrm{H}^{\prime}\right)$ :

$H^{\prime}=-\sum_{i=1}^{S} p_{i} \ln \left(p_{i}\right)$

where $p_{i}$ is the relative abundance (share of the total number of stems) of each species $(i=1,2, \ldots, S)$ (Krebs 1999). Shannon diversity index was selected as it accounts for abundance and evenness of both species. Shannon index was set to zero when there were no trees present in the plots. 


\subsection{Aboveground biomass and carbon stock}

187 Tree aboveground biomass (AGB) was computed using the most recent pan-tropical biomass models (Chave et al. 2014) because of the absence of local, species-specific allomeric equations. The model is based on $\mathrm{DBH}(\mathrm{cm}), \mathrm{H}(\mathrm{m})$ and wood-specific 190 gravity $\left(\rho, g / \mathrm{m}^{3}\right)$ :

$191 A G B=0.06773\left(\rho \times D B H^{2} \times H\right)^{0.976}$.

192 The values of $\rho$ were sourced from online databases (Zanne et al. 2010, World Agroforestry Center 2015) to the closest taxonomic unit. As a result, $83.3 \%$ of stems had $\rho$ available for species level, $93.2 \%$ for genus level and $93.4 \%$ for family level. For the unknown species, a site-specific mean value was used. AGB of palms was computed using the function of Frangi and Lugo (1985) based on height. Finally, AGB was converted to tree AGC stock $\left(\mathrm{Mg} \mathrm{ha}^{-1}\right)$ using a carbon fraction of 0.47 (IPCC 2006, Paustian et al. 2006).

\subsection{Soil carbon stock}

Two types of soil samples were collected in the field: composite and cumulative mass samples They were collected using a soil auger with a sampling plate as auger guide, press firmly onto the soil. The auger was marked at 20,50, 80 and $110 \mathrm{~cm}$. The composite samples were collected at sub-plot (0.01ha) level and used for the analysis of carbon content, while cumulative mass soil samples were collected to estimate bulk density, which is required to calculate SOC stocks (Aynekulu et al. 2011).

Top $(0-20 \mathrm{~cm})$ and sub $(20-50 \mathrm{~cm})$ soil samples were collected from the centre of each sub-plot. There were restrictions below $20 \mathrm{~cm}$ depth in most of the plots. 
However, 0-20 cm depth was free of restriction in all the plots, and since most of the SOC is concentrated in the top $0-10 \mathrm{~cm}$ depth (Corbeels et al. 2016), we used only soil samples from 0-20 cm depth in this study. Therefore, samples with 0-20 cm depth were collected from sub-plots, mixed and a composite sample taken for laboratory analysis. SOC concentration $\left(\mathrm{g} \mathrm{kg}^{-1}\right)$ was analysed using a thermal oxidation method (Liang et al. 2008, Skjemstad and Baldock 2008) in the soil laboratory of the World Agroforestry Centre in Nairobi, Kenya. To avoid the influence of inorganic carbon (carbonate), samples were treated with hydrochloric acid to remove the inorganic carbon (Harris et al. 2001). The gravimetric moisture content on a subsample was determined to calculate the actual oven-dried $\left(105^{\circ} \mathrm{C}\right)$ mass of the respective samples. SOC stock $\left(\mathrm{Mg} \mathrm{C} \mathrm{ha-1}^{-1}\right)$ was calculated as: SOC stock $=\mathrm{C} / 100 \times \rho \times \mathrm{D} \times 10000$, where $\mathrm{C}$ is the soil organic concentration of fine soil fraction $(<2 \mathrm{~mm}$ diameter) determined in the laboratory (\%), $\rho$ is dry soil bulk density fine soil fraction $\left(\mathrm{Mg} \mathrm{m}^{-3}\right), \mathrm{D}$ is thickness of the sampled soil layer (m), and 10000 is a factor for converting $\mathrm{Mg} \mathrm{C} \mathrm{m}^{-2}$ to $\mathrm{Mg} \mathrm{C}$ $\mathrm{ha}^{-1}$. SOC stock calculation was determined for the fine soil mass by excluding stones volume of the soil for the $20 \mathrm{~cm}$ soil thickness was $907 \mathrm{~cm}^{3}$.

\subsection{Statistical analysis}

First, the plot-level values were used for computing descriptive statistics (mean, range and standard deviation) for the landscape. Next, AGC, SOC, species richness and Shannon index were analysed according to vegetation types. Kruskal-Wallis and pairwise Wilcoxon rank-sum tests were conducted to study if differences between the vegetation types were statistically significant. The non-parametric tests were used 
because the data set did not satisfy the assumptions of parametric tests. Bar plots were used to visualize how variables depended on grouping. Also, tree species composition between the vegetation types was compared, and stem density, AGC and species richness were studied according to the diameter class. Finally, the relationships between the carbon and tree species diversity variables were investigated using correlation analysis (Spearman's rank correlation coefficient). All the analyses were performed in $\mathrm{R}$ statistical software version 3.1.0 ( $\mathrm{R}$ Core Team 2015).

\section{Results}

\subsection{Carbon and tree species diversity at landscape level}

AGC ranged from 0.2 to $113.1 \mathrm{Mg} \mathrm{C}^{-1}$ with a mean of $29.4 \mathrm{Mg} \mathrm{C}^{-1}$ ha ${ }^{-1}$ 21.3) (Table 2). SOC for depth $0-20 \mathrm{~cm}$ varied less than AGC but had higher mean value of $42.2 \mathrm{Mg} \mathrm{C} \mathrm{ha-1} \mathrm{(SD} \mathrm{20.6).} \mathrm{Tree} \mathrm{species} \mathrm{richness} \mathrm{varied} \mathrm{between} 1$ and 17 with a mean of 7 species per plot (SD 4). Shannon index revealed a minimum and maximum of 0 and 2.4 with a mean of 1.6 (SD 0.6). In total, 90 tree species were recorded, but scientific names could not be identified for 29 species (6.8\% of the stems). The identified species belonged to 18 families and 53 genera. Fabaceae (Leguminosae) accounted for the largest number of species (19 species) followed by Anacardiaceae (5), Annonaceae, Combretaceae, Malvaceae and Rubiaceae (4). Gmelina arborea, an exotic tree species, showed the highest abundance (12.7\%) in terms of stem count (Fig. 4). Indigenous species, Combretum glutinosum (12.5\%), Pterocarpus erinaceous (9.2\%) and Terminaria glaucescens (6.4\%), were also common in the landscape. The same species accounted for the 
highest amount of AGC stock. P. erinaceous contributed to the largest AGC share

259

260

261

262

263

264

265

266

267

268

269

270

271

272

273

274

275

276

277

278

279

280

281

(16.8\%) followed by G. arborea (14.7\%), C. glutinosum (11.9\%) and T. glaucescens (7.8\%).

When analysing the data by $\mathrm{DBH}$ class (Table 3), it was evident that there were a large number of small stems $(4-10 \mathrm{~cm})$, which made only minor contributions to the total AGC. The number of stems decreased continuously towards the larger diameter classes. In terms of AGC, the most important DBH classes were between 10.1 and 50 $\mathrm{cm}$, accounting for more than two-thirds of the total AGC stock (80.4\%), with each class covering more than $10 \%$ of the total. Similarly, DBH range $4-50 \mathrm{~cm}$ accounted for the highest number of species, each covering more than $12 \%$ of the total number of species. Furthermore, the largest trees $(\mathrm{DBH}>60 \mathrm{~cm})$ covered a major fraction of the total AGC (11.7\%), considering the small fraction of the total number of stems $(0.4$ $\%)$.

\subsection{Carbon and tree species diversity in different vegetation types}

In total, data were collected from 160 plots with different vegetation types: forest (29), bushland (11), cropland (25), wooded grassland (27) and woodland (68). The KruskalWallis test revealed that all the variables differed significantly $(p<0.001)$ between the vegetation types. According to the Wilcoxon test (Fig. 5a), mean AGC of the forest (40.1 Mg C ha-1, SD 24.6) and woodland (39.8 $\mathrm{Mg} \mathrm{C} \mathrm{ha}^{-1}, \mathrm{SD} 12.1$ ) were significantly

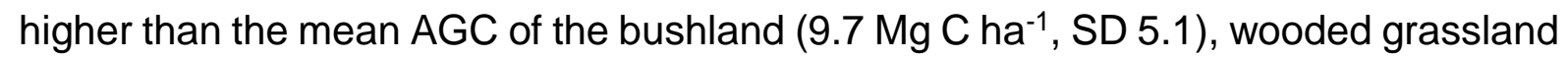

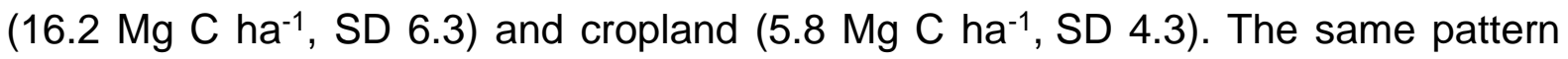
applied to species richness (Fig. 5c). Mean SOC of the forest (56.7 Mg C ha-1 $\mathrm{SD}$ 18.7) was significantly higher than that of the woodland (37.9 $\mathrm{Mg} \mathrm{C} \mathrm{ha-1}^{-1}$ SD 19.1), 
wooded grassland (37.3 $\left.\mathrm{Mg} \mathrm{C} \mathrm{ha-1}^{-1}, \mathrm{SD} 29.7\right)$ and cropland (36. $\mathrm{Mg} \mathrm{C}^{-1} \mathrm{ha}^{-1}, \mathrm{SD} 19.9$ )

283

284

285

286

287

288

289

290

291

292

293

294

295

296

297

298

299

300

301

302

303

304

305

(Fig. 5b). Also, cropland had a significantly lower Shannon index (0.7, SD 0.5) than forest (1.5, SD 0.6), woodland (1.6, SD 0.4) and wooded grassland (1.2, SD 0.5) (Fig. 5d).

When analysing the data by $\mathrm{DBH}$ class and vegetation type, it was evident that the large trees $(\mathrm{DBH}>60 \mathrm{~cm})$ accounted for a large fraction of $A G C$ in all vegetation types in comparison to a number of stems (Table 4). However, the contribution of the large trees to the total AGC was the greatest in forest and bushland.

\subsection{Relationships between AGC, SOC and tree species diversity}

The results of the correlation analysis between the different variables are shown in Fig. 6. The correlation between AGC and SOC was weak $(r=0.170)$ but statistically significant $(p<0.05)$ (Fig. 6a). There was a moderate correlation between AGC and species richness $(r=0.475, p<0.001)(F i g .6 b)$ and between AGC and Shannon index $(r=0.375, p<0.001)$ (Fig. 7d). However, the correlations between SOC and species richness (Fig. 6c) or between SOC and Shannon index (Fig. 6e) were not significant.

\section{Discussion}

The results of this study present carbon stocks and tree species diversity for a Guinean savannah landscape in Northern Sierra Leone. Therefore, the results do not provide a representative sample for the country's savannah biome, which comprises $25 \%$ of the country's vegetation area. However, the mean AGC in the landscape (29.4 Mg C $\mathrm{ha}^{-1}$, SD 21.3) is comparable to that reported by Bouvet et al. (2018) for savannah and woodland landscapes in Sierra Leone (24.7 $\left.\mathrm{Mg} \mathrm{ha}^{-1}\right)$. In addition, Guinea (25.7 Mg 
$\left.\mathrm{ha}^{-1}\right)$ and Ivory Coast $\left(21.6 \mathrm{Mg} \mathrm{ha}^{-1}\right)$ had comparable mean densities to Sierra Leone while Ghana (14.7 $\left.\mathrm{Mg} \mathrm{ha}^{-1}\right)$ and Burkina Faso $\left(8.5 \mathrm{Mg} \mathrm{ha}^{-1}\right)$ had lower densities according to the remote-sensing study of Bouvet et al. (2018). Relatively high AGC in the region could be attributed to high precipitation in the area (Sankaran et al. 2005) compared to other savannah and woodland landscapes in Africa. Mean AGC in the study area was similar to the Miombo woodlands in Tanzania $\left(29.8 \pm 13.1 \mathrm{Mg} \mathrm{C}^{-1}\right)$ (Ribeiro et al. 2013), but higher than the mean for woodlands in Taita Hills in Kenya (15.6 Mg C ha-1) (Pellikka et al. 2018) and the dry Afromontane forest in Northern Ethiopia (19.3 $\pm 3.9 \mathrm{Mg} \mathrm{C} \mathrm{ha-1}^{-1}$ ) (Mokria et al. 2015).

Mean SOC in the study area (42.2 $\left.\mathrm{Mg} \mathrm{C} \mathrm{ha-1}^{-1}, \mathrm{SD} 20.6\right)$ was comparable to the Miombo woodlands (34.72 $\pm 17.93 \mathrm{Mg} \mathrm{C} \mathrm{ha}^{-1}$ ) (Ribeiro et al. 2013) but greater than in the Guinean savannah in Ghana (Djagbletey and Logah 2018) and Senegal's Sahel Transition Zone (Woomer et al. 2004). The increase in SOC is an indication of good soil properties and high precipitation in the landscape. High precipitation (Hijmans et al. 2005) and long-lasting precipitation (Gomez Paloma and Acs 2012) and high clay content (Jones 1973) positively affect SOC sink, while high disturbance (e.g. slashand-burn farming, timber harvesting) had a negative influence on the SOC sink on the landscape (CILSS 2016).

The tree species richness in the landscape was high with G. arborel, C. glutinosum, $P$. erinaceous and $T$. glaucescens as the most abundance species. This is typical of West African Guinean savannah (Addo-Fordjour et al. 2009). Tree species richness is comparable to the Sudanian savannah (Dayamba et al. 2016) and the woodlands of Ngomakurira Mountain in Zimbabwe (Zimudzi et al. 2016) but higher than in the semiarid and arid regions of southwestern Niger (Mahamane and Mahamane 2005). Anthropogenic activities (e.g. farming timber harvesting, wood collection) and wild fires 
are major drivers responsible for reduction in the species richness in the landscape. P. erinaceous (African rosewood) and G. arborea (Yamane) are among the widely harvested timber species by the local communities for domestic and commercial purposes. G. arborea was introduced to Sierra Leone from Thailand as part of a nationwide plantation forest programme established mainly in community lands (Savill and Fox 1967) and edges of protected forests (Anon. 1996). Although it was planted in specific areas, now $G$. arborea is visible in every part of the landscape because the seeds are dispersed by herbivores (e.g. cattle), spread fast and could be considered invasive.

The stem numbers in the landscape shows a $\mathrm{J}$ pattern by $\mathrm{DBH}$ class, indicating potential to regenerate due to the presence of many stems in the small diameter size classes (Zimudzi and Chapano 2016). Furthermore, high AGC was evident in few trees with large DBH class that contributed a significant proportion of the total AGC in the landscape. Also, the number of stems decreased with increasing DBH. The mean stem number was higher than in other savannah types, such as in Burkina Faso (Dayamba et al. 2016) and Miombo woodlands in the Eastern Arc Mountains in Tanzania (Shirima et al. 2011). This could be associated with the relatively high rainfall in the area (ca $2400 \mathrm{~mm}$ year $^{-1}$ ) compared to other savannah regions. The high proportion of stems in the lower $\mathrm{DBH}$ classes and the inverse J-shaped diameter distribution indicate regeneration (Chamshama et al. 2007, Nduwayezu et al. 2015) and support ecosystem productivity in the landscape. The low stocking of larger diameter tree classes could be associated mainly to the high rate of illegal timber harvesting and slash-and-burn farming in the region. Fire and unsustainable harvesting of non-timber forest products (NTFP) could also contribute to this pattern. 
overall stability of the plant communities at the landscape level is moderate because plant community stability is known to be dependent on its diversity (Lhomme and Winkel 2002).

Forests are less influenced by fire than the woodland and wooded grassland but more targeted by farmers and timber harvesters because of their tree species composition and soil nutrients. Although seriously targeted, forests have the largest mean AGC in the landscape. Woodlands are less used for farming because of poor soil nutrients and hold the second-largest mean AGC. However, woodlands are also seriously threatened by logging as those are the main habitat for many tree species used for timber (e.g. P. erinaceous). A few large trees were found to make a large contribution to AGC in bushlands and croplands. This could be associated with farmers practicing agroforestry during slash-and-burn farming or in their permanent farms. In this case, farmers keep some trees on the farm based on the value they have for them (e.g. provide fruits, shade and soil conservation). SOC showed significant differences among the vegetation types - forest showing the greatest mean SOC - which agrees with Akpa et al. (2016). High SOC in the forests could be associated with a high decomposition rate in forest soil because of low temperatures provided by overlocking canopies and high moisture, microbial activities and less disturbance from fire. Furthermore, most of the forests (gallery forest) are close to water bodies and have enough soil moisture for decomposition of dead biomass (Wang et al. 2012). Significant differences among the vegetation types were observed in terms of biodiversity, and forest, woodland and wooded grassland had higher species richness and Shannon index than other classes (bushland and cropland). This may, however, contribute to the high carbon content of these vegetation types. 
Species richness showed very high linear correlation with Shannon diversity index.

381

382

This implies that with increasing species richness, diversity (heterogeneity) also increases (Tramer 1969). Other significant relationships were between tree species diversity (both richness and Shannon index) and AGC, all showing a moderate positive relationship. It was clearly revealed that an increase in tree species diversity gives a corresponding increase in AGC in the studied landscape. This implies that ecosystem productivity (biomass) depends on biodiversity and total biomass depends on tree species richness and composition (Tilman et al. 1997) similar to some of the earlier studies (Strassburg et al. 2010b, Gamfeldt et al. 2013, Shirima et al. 2015, Mensah et al. 2016b).

The studied landscape had high carbon stock and tree species diversity (species richness and Shannon index). Therefore, robust management of the natural resources (forests) through community participation, especially in the Kuru Hills Forest Reserve, will improve ecosystem productivity and stability, which support carbon sequestration and storage in the landscape. Increasing forest cover, especially in the Kuru Hills, would increase water resources similarly as in the Taita Hills, Kenya, due to increased ability to capture atmospheric moisture and to store water resources in forested landscapes (Hohenthal et al. 2015, Cardwell 2017). Furthermore, the establishment and protection of community forests by government, communities and nongovernmental organisations (NGOs) in this landscape will increase the area's ability to mitigate climate change through carbon sequestration. Finally, sustainable farming (e.g. agroforestry) and regulatory harvesting of ecosystem products by community members will decrease the release of carbon from the region.

\section{Conclusion}


405 The humid Guinean savannah in Northern Sierra Leone is a high carbon and

406

407

408

409

410

411

412

413

414

415

416

417

421

422

423

424

425

biodiversity pool and contributes to global climate change mitigation through carbon sequestration and storage. Tree species diversity (biodiversity) moderately contributed to the high carbon stock in the landscape. Other factors such as precipitation and soil could be responsible for the increase in the soil carbon stock. Furthermore, the inverse J-shaped distribution of the stem numbers by DBH class demonstrates high regeneration that increase carbon in the landscape, which supports future climate change mitigation in the landscape. Forests and woodland are the most important pools for biodiversity and carbon. Management of these vegetation types together with the others will improve the biodiversity and carbon status of this region to benefit from REDD+. Sustainable farming (e.g. agroforestry), timber and pole harvesting, NTFP harvesting and fire management will reduce biodiversity and carbon loss in the landscape. Enforcing the management of protected forests and creating more community forests will increase carbon sequestration and biodiversity in the landscape with a contribution to global climate change mitigation.

\section{Acknowledgements}

This study was funded by the Ministry for Foreign Affairs of Finland through the Building bio-carbon and rural development in West Africa project (BIODEV). Thanks are due to the field inventory crew from the Sierra Leone Agricultural Research Institute and Biodiversity Conservation Project Sierra Leone. Petri Pellikka was supported by the Finnish Culture Foundation through a project Remote sensing of water harvesting and carbon sequestration by forests in the Taita Hills, Kenya, and by the Academy of Finland through a project Integrated land cover-climate-ecosystem 
429 process study for water management in East African highlands. The comments by the 430 two anonymous reviewers are also highly appreciated. 


\section{References}

433

434

435

436

437

438

439

440

441

442

443

444

445

446

447

448

449

450

451

452

Abreu RCR, Hoffmann WA, Vasconcelos HL, Pilon NA, Rossatto DR, Durigan G. 2017. The biodiversity cost of carbon sequestration in tropical savanna. Science Advances 3: e1701284.

Anderson JM. 1991. The effects of climate change on decomposition processes in grassland and coniferous forests. Ecological Applications 1: 326-347.

Anon. 1996. Sierra Leone: country report to the FAO international technical conference on plant genetic resources (Leipzig, 1996). Compiled by: Department of Agriculture and Forestry, Freetown.

Apa SIC, Odeh IOA, Bishop TFA, Hartemink AE, Amapu IY. 2016. Total soil organic carbon and carbon sequestration potential in Nigeria. Geoderma 271: 202-215.

Asabi A-AO, Kwasi FM, Albert DN. 2013. Assessment of the effects of density on the mechanical property's variations of Borassus aethiopum. Archives of Applied Science Research 5: 6-19.

Avitabile V, Herold M, Heuvelink GBM, Lewis S L, Phillips OL, Asner GP, Armston J, Ashton PS, Banin L, Bayol N, Berry NJ, Boeckx P, de Jong BH, DeVries B, Girardin CA, Kearsley E, Lindsell JA, Lopez-Gonzalez G, Lucas R, Malhi Y, Morel A, Mitchard ET, Nagy L, Qie L, Quinones MJ, Ryan CM, Ferry SJ, Sunderland T, Laurin GV, Gatti RC, Valentini R, Verbeeck H, Wijaya A, Willcock S. 2016. An integrated pan-tropical biomass map using multiple reference dataset. Global Change Biology 22: 14061420. 
453 Aynekulu E, Vågen T-G, Shephard KD, Winowiecki L. 2011. A Protocol for Modelling,

Measurement and Monitoring Soil Carbon Stocks in Agricultural Landscapes. Version.

456 Bombelli A, Henry M, Castaldi S, Adu-Bredu S, Arneth A, de Grandcourt A, Grieco E, 457 Kutsch WL, Lehsten V, Rasile A, Reichstein M, Tansey K, Weber U, Valentin R. 2009. An outlook on the Sub-Saharan Africa carbon balance. Biogeosciences 6: 2193-2205.

Bonan GB. 2008. Forests and Climate Change: Forcing Feedbacks, and the Climate Benefits of Forests. Science 320: 1444-1449.

Bouvet A, Mermoz S, Le Toan T, Villard L, Mathieu R, Naidoo L, Asner GP. 2018. An above-ground biomass map of African savannahs and woodlands at $25 \mathrm{~m}$ resolution derived from ALOS PALSAR. Remote Sensing of Environment 206: 156-173.

Cardwell A. 2017. The effect of land use on infiltration in Taita Hills Kenya. MSc thesis, 465 University of Helsinki, Finland

Carvalhais N, Forkel M, Khomik M, Bellarby J, Jung M, Migliavacca M, Mu M, Saatchi

S, Santoro M, Thurner M, Weber U, Ahrens B, Beer C, Cescatti A, Randerson JT, Reichstein M. 2014. Global covariation of carbon turnover times with climate in terrestrial ecosystems. Nature 514: 213-217

CEPF. 2000. Ecosystem Profile: Upper Guinean Forest ecosystem of the Guinean

471 Forests of West Africa Biodiversity Hotspot. Critical Ecosystem Partnership Fund, 472 Arlington, USA.

Chamshama SAO, Mugasha AG, Zahabu E. 2004. Stand Biomass and Volume 474 Estimation for Miombo Woodlands at Kitulangalo, Morogoro, Tanzania. Southern 475 African Forestry Journal 200: 59-69. 
476 Chave J, Réjou-Méchain M, Búrquez A, Chidumayo E, Colgan MS, Delitti WBC, 477 Vieilledent G. 2014. Improved allometric models to estimate the aboveground biomass 478 of tropical trees. Global Change Biology 20: 3177-3190.

479 Chen X. 2006. Tree Diversity, Carbon Storage, and Soil Nutrient in an Old-Growth 480 Forest at Changbai Mountain, Northeast China. Communications in Soil Science and 481 Plant Analysis 37: 363-375.

482 CILSS. 2016. Landscapes of West Africa - A Window on a Changing World. 483 Garretson: U.S. Geological Survey.

Clark DB, Clark DA. 2000. Landscape-scale variation in forest structure and biomass 485 in a tropical rain forest. Forest Ecology and Management 137: 185-198.

Corbeels M, Marchão RL, Neto MS, Ferreira EG, Madari BE, Scopel E, Brito OR. 2016. Evidence of limited carbon sequestration in soils under no-tillage systems in the Cerrado of Brazil. Scientific Reports 6: 1-8.

Curtis RO. 1967. Height-diameter and height-diameter-age equations for secondgrowth Douglas-fir. Forest Science 13: 365-375.

Dayamba SD, Djoudi H, Zida M, Sawadogo L, Verchot, L. 2016. Biodiversity and carbon stocks in different land use types in the Sudanian Zone of Burkina Faso, West Africa. Agriculture, Ecosystems \& Environment 216: 61-72.

Eswaran H, Vandenberg E, Reich P. 1993. Organic carbon in soils of the world. Soil Science Society of America Journal 57: 192-194.

Frangi JL, Lugo AE. 1985. Ecosystem Dynamics of a Subtropical Floodplain, forest

497 Ecosystem dynamics of a subtropical floodplain in forest. Ecological Monographs 55: 351-369. 
499 Gamfeldt Lefcheck JS, Byrnes JEK, Cardinale BJ, Duffy JE, Griffin JN. 2015. Marine 500 biodiversity and ecosystem functioning: What's known and what's next? Oikos 124: $252-265$.

502 Gamfeldt L, Snäll T, Bagchi R, Jonsson M, Gustafsson, L, Kjellander P, Ruiz-Jaen 503 MC, Fröberg M, Stendahl J, Philipson CD, Mikusiski G, Moen J, Bengtsson J. 2013. Higher levels of multiple ecosystem services are found in forests with more tree species. Nature Communications 4: 1340.

506 Gomez Paloma S, Acs S. 2012. Rural poverty reduction and food security: The case 507 of smallholders in Sierra Leone. Luxembourg: Publications Office of the European 508 Union.

Grace J, Jos JS, Meir P, Miranda HS, Montes RA. 2006. Productivity and carbon fluxes of tropical savannas. Journal of Biogeography 33: 387-400.

Harris D, Horwáth WR, van Kessel C. 2001. Acid fumigation of soils to remove carbonates prior to total organic carbon or Carbon-13 isotopic analysis. Soil Science Society of America Journal 65: 1853. Heikinheimo V. 2015. Impact of land cover change on aboveground carbon stocks in the Taita Hills, Kenya. MSc thesis, University of Helsinki, Finland.

516 Higgins SI, Bond WJ, February EC, Bronn A, Euston-Brown DIW, Enslin B, Trollope 517 WSW. 2007. Effects of four decades of fire manipulation on woody vegetation structure in savanna. Ecology 88: 1119-1125. interpolated climate surfaces for global land areas. International Journal of Climatology 25: 1965-1978. 
522 Hohenthal J, Owidi E, Minoia P, Pellikka PKE. 2015. Local assessment of changes in 523 water-related ecosystem services and their management: Dpaser conceptual model 524 and its application in Taita Hills, Kenya. International Journal of Biodiversity Science, 525 Ecosystem Services \& Management 11:225-238.

526 Houghton RA, Hall F, Goetz SJ. 2009. Importance of biomass in the global carbon 527 cycle. Journal of Geophysical Research: Biogeosciences 114: 1-13.

528 Isango JA. 2007. Stand Structure and Tree Species Composition of Tanzania Miombo

529 Woodlands: A Case Study from Miombo Woodlands of Community Based Forest 530 Management in Iringa district. Working Papers of the Finnish Forest Research Institute 531 50: 43-56.

532 IPCC (2006). 2006 IPCC guidelines for national greenhouse gas inventories. 533 Eggleston HS, Buendia L, Miwa K, Ngara T, Tanabe K (eds). Hayama: Institute for 534 Global Environmental Strategies (IGES).

535 Jackson R, Banner J, Jobbágy E. 2002. Ecosystem carbon loss with woody plant 536 invasion of grasslands. Nature 277: 623-627.

537 Jeltsch F, Weber GE, Grimm V. 2017. Ecological buffering mechanisms in savannas: 538 a unifying theory of long-term tree-grass. Plant Ecology 150: 161-171.

539 Jones MJ. 1973. The Organic Matter Content of the Savanna Soils of West Africa. Soil $540 \quad$ Science 24: 42-53.

541 Kirby KR, Potvin C. 2007. Variation in carbon storage among tree species: Implications 542 for the management of a small-scale carbon sink project. Forest Ecology and 543 Management 246: 208-221. 
Laurance WF. 2008. Can Carbon Trading Save Vanishing Forests? BioScience 58: 286.

546 Lhomme JP, Winkel T. 2002. Diversity-Stability Relationships in Community Ecology:

547 Re-Examination of the Portfolio Effect. Theoretical Population Biology 62: 271-279.

548 Liang B, Lehmann J, Solomon D, Sohi S, Thies JE, Skjemstad JO, Wirick S. 2008.

549 Stability of biomass-derived black carbon in soils. Geochimica et Cosmochimica Acta $550 \quad 72: 6069-6078$.

Lugo AE. 1985. Ecosystem Dynamics of a Subtropical Floodplain Forest. Ecological Monographs 55: 351-369.

Mahamane L, Mahamane S. 2005. Biodiversity of ligneous species in semi-arid to arid zones of southwestern Niger according to anthropogenic and natural factors. Agriculture Ecosystems \& Environment 105: 267-271

Majumdar K, Choudhary BK, Datta BK. 2016. Aboveground Woody Biomass, Carbon

557 Stocks Potential in Selected Tropical Forest Patches of Tripura, Northeast India. Open 558 Journal of Ecology 6: 598-612.

Mathew MM, Majule AE, Sinclair F, Marchant R. 2016. Relationships between on-farm tree stocks and soil organic carbon along an altitudinal gradient, Mount Kilimanjaro,

561 Tanzania. Forests Trees and Livelihoods 25: 255-266.

Mensah S, Veldtman R, Du Toit B, Kakaï RG, Seifert T. 2016. Aboveground biomass and carbon in a South African Mistbelt forest and the relationships with tree species diversity and forest structures. Forests 7: 79. 
565 Mokria M, Gebrekirstos A, Aynekulu E, Bräuning A. 2015. Tree dieback affects climate 566 change mitigation potential of a dry Afromontane forest in northern Ethiopia. Forest 567 Ecology and Management 344: 73-83.

568 Nduwayezu JB, Mafoko GJ, Mojeremane W, Mhaladi LO. 2015. Vanishing 569 multipurpose indigenous trees in Chobe and Kasane Forest Reserves of Botswana. 570 Resources and Environment 5: 167-172.

571 Pan Y, Birdsey RA, Fang J, Houghton R, Kauppi PE, Kurz WA, Phillips OL, Shvidenko 572 A, Lewis SL, Canadell JG, Ciais P, Jackson RB, Pacala SW, McGuire AD, Piao S, 573 Rautiainen A, Sitch S, Hayes D. 2011. A Large and Persistent Carbon Sink in the 574 World's Forests. Science 333: 988-993.

575 Pellegrini AFA, Hedin LO, Staver AC, Govender N, Henry HAL. 2015. Fire alters 576 ecosystem carbon and nutrients but not plant nutrient stoichiometry or composition in 577 tropical savanna. Ecology 96: 1275-1285.

578 Pinheiro J, Bates D, DebRoy S, Sarkar D. 2014. nlme: Linear and Nonlinear Mixed 579 Effects Models. R package version 3.1-117.

580 R Core Team. 2015. R: A Language and Environment for Statistical Computing. 581 Vienna: R Foundation for Statistical Computing.

582 Ribeiro NS, Matos CN, Moura IR, Washington-Allen RA, Ribeiro Al. 2013. Monitoring 583 vegetation dynamics and carbon stock density in miombo woodlands. Carbon Balance 584 and Management 8: 11.

585 Saatchi SS, Harris NL, Brown S, Lefsky MA, Mitchard ET, Salas W, Lewis SL, Hagen 586 S, Petrova S, White L, Silman M, Morel A, Susan Trumbore by E. 2011. Benchmark 
map of forest carbon stocks in tropical regions across three continents. Proceedings of the National Academy of Sciences of the United States of America 24: 9899-9904.

Saha SK, Nair PKR, Nair VD, Kumar BM. 2009. Soil carbon stock in relation to plant diversity of home gardens in Kerala, India. Agroforestry Systems 76: 53-65.

Sankaran M, Hanan NP, Scholes RJ, Ratnam J, Augustine DJ, Cade BS, Gignoux J, Higgins SI, Le Roux X, Ludwig F, Ardo J, Banyikwa F, Bronn A, Bucini G, Caylor KK, Coughenour MB, Diouf A, Ekaya W, Feral CJ, February EC, Frost PGH, Hiernaux P, Hrabar H, Metzger KL, Prins HHT, Ringrose S, Sea W, Tews J, Worden J, Zambatis N. 2005. Determinants of woody cover in African savannas. Nature 438: 846-849 Savill PS, Fox JED. 1967. Trees of Sierra Leone. Freetown: Forest department.

Scholes RJ, Archer SR. 1997. Tree-Grass Interactions in Savannas. Annual Review of Ecology, Evolution, and Systematics 28: 517-544.

Scholes RJ, Hall D. 1996. The carbon budget of tropical savannas, woodlands and grasslands. In: Breymeyer GAI, Hall ID, Melillo JM, Agren GI (eds), Global change, effects on coniferous forest and grasslands. New York: John Wiley. pp. 69-100.

Sharma CM, Baduni NP, Gairola S, Ghildiyal SK, Suyal, S. 2010. Tree diversity and carbon stocks of some major forest types of Garhwal Himalaya, India. Forest Ecology and Management 260: 2170-2179.

Shirima DD, Munishi PKT, Lewis SL, Burgess ND, Marshall AR, Balmford A, Swetnam, RD, Zahabu EM. 2011. Carbon storage, structure and composition of miombo woodlands in Tanzania's Eastern Arc Mountains. African Journal of Ecology 49: 332342. 
Shirima DD, Totland $\varnothing$, Munishi PKT, Moe SR. 2015. Relationships between tree species richness, evenness and aboveground carbon storage in montane forests and miombo woodlands of Tanzania. Basic and Applied Ecology 16: 239-249.

Soepadmo E. 1993. Tropical rain forest as carbon sink. Chemosphere 27: 1025-1039.

Strassburg BBN, Kelly A, Balmford A, Davies RG, Gibbs HK, Lovett A, Miles L, Orme CDL, Price J, Turner RK, Rodrigues ASL. 2010. Global congruence of carbon storage and biodiversity in terrestrial ecosystems. Conservation Letters 3: 98-105.

Takimoto A, Nair PKR, Nair VD. 2008. Carbon stock and sequestration potential of traditional and improved agroforestry systems in the West African Sahel. Agriculture, Ecosystems \& Environment 125: 159-166.

Thomas CD, Thomas CD, Cameron A, Cameron A, Green RE, Green RE, Bakkenes M, Bakkenes M, Beaumont LJ, Beaumont LJ, Collingham YC, Collingham YC, Erasmus BFN, Erasmus BFN, De Siqueira MF, De Siqueira MF, Grainger A, Grainger A, Hannah L, Hannah L, Hughes L, Hughes L, Huntley, B, Huntley B, Van Jaarsveld AS, Van Jaarsveld AS, Midgley GF, Midgley GF, Miles L, Miles L, Ortega-Huerta MA, Ortega-Huerta MA, Peterson AT, Peterson AT, Phillips OL, Phillips OL, Williams SE Williams SE. 2004. Extinction risk from climate change. Nature 427: 145-148.

Tilman D, Knops J, Wedin D, Reich P, Ritchie M, Siemann E. 1997. The Influence of Functional Diversity and Composition on Ecosystem Processes. Science 277: 13001302.

Tramer EJ. 1969. Bird Species Diversity: Components of Shannon's Formula. Ecology 50: 927-929. 
631 Vågen T.-G, Winowiecki LA, Tamene Desta L, Tondoh JE. 2013. Land Degradation

632 Surveillance Framework (LDSF) - Field Guide. Available online at:

633 https://www1.cifor.org/fileadmin/subsites/sentinel-

634 landscapes/document/LDSF Field Guide.pdf [accessed 1 October 2018].

635 Valbuena R, Heiskanen J, Aynekulu E, Pitkänen S, Packalen P. 2016. Sensitivity of 636 Above-Ground Biomass Estimates to Height-Diameter Modelling in Mixed-Species 637 West African Woodlands. Plos One 11: e0158198.

638 Wang S, Fu BJ, Gao GY, Yao XL, Zhou J. 2012. Soil moisture and evapotranspiration 639 of different land cover types in the Loess Plateau, China. Hydrology and Earth System 640 Sciences 16: 2883-2892.

641 White F. 1983. The vegetation of Africa: a descriptive memoir to accompany the 642 UNESCO/AETFAT/UNSO vegetation map of Africa. Paris: Unesco.

643 Woomer PL, Touré A, Sall M. 2004. Carbon stocks in Senegal's Sahel Transition 644 Zone. Journal of Arid Environments 59: 499-510.

645 World Agroforestry Centre. 2015. Tree Functional Attributes and Ecological Database.

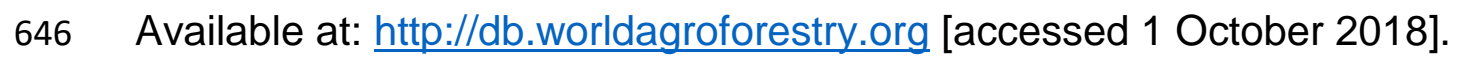

647 Zanne AE, Lopez-Gonzalez G, Coomes D, Ilic J, Jansen S, Lewis S, Miller R, Swenson 648 N, Wiemann M, Chave J, Lopez-Gonzalez G. 2009. Data from: Towards a worldwide 649 wood economics spectrum. Available at: https://doi.org/10.5061/dryad.234 [accessed 6501 October 2018].

651 Zimudzi C, Chapano C, Zimudzi C, Chapano C. 2016. Diversity, Population Structure, 652 and Above Ground Biomass in Woody Species on Ngomakurira Mountain, 653 Domboshawa, Zimbabwe. International Journal of Biodiversity 2016: 1-11. 


\section{$654 \quad$ Figure captions}

655 Figure 1. Location of the study area in Northern Sierra Leone, and clusters of the field 656 plots (each cluster consist of ten plots) within the study area with the boundaries of the 657 Kuru Hills Forest Reserve.

658 Figure 2. (a) Forest on the slopes of the Kuru Hills, (b) bushland with the Kuru Hills in 659 the background, (c) woodland in the plateau, (d) wooded and partly burned grassland, 660 (e) cropland and (f) Kuru Hills rising from the plateau covered by bushland. Note the 661 smoke from the wildfires in the air. Photos by P. Pellikka, 2014.

662 Figure 3. Sample plot design with 0.1 ha plot and four 0.01 ha sub-plots.

663 Figure 4. The relative abundance (\%) of the most common tree species in the 664 landscape in terms of AGC and number of stems.

Figure 5. Comparison of (a) AGC, (b) SOC stock in the top 0-20 cm depth, (c) tree species richness and (d) Shannon index between vegetation types. Wooded gr. = 667 wooded grassland.

Figure 6. The relationships of carbon stock and tree species diversity variables: (a) AGC vs. SOC, (b) tree species richness vs. AGC, (c) tree species richness vs. SOC,

(d) Shannon index vs. AGC, (e) Shannon index vs. SOC and (f) species richness vs.

671 Shannon index. 
673 Table captions

674 Table 1. Vegetation types used for grouping the field plots.

675 Table 2. Variation in AGC, SOC at 0-20 cm depth, species richness and Shannon 676 index at landscape-level $(n=160)$.

677 Table 3. Relative abundance (\%) of stems, AGC and species in DBH classes.

678 Table 4. Relative abundance (\%) of the large trees $(\mathrm{DBH}>60 \mathrm{~cm})$ in terms of stems 679 and aboveground carbon (AGC) in different vegetation types. 


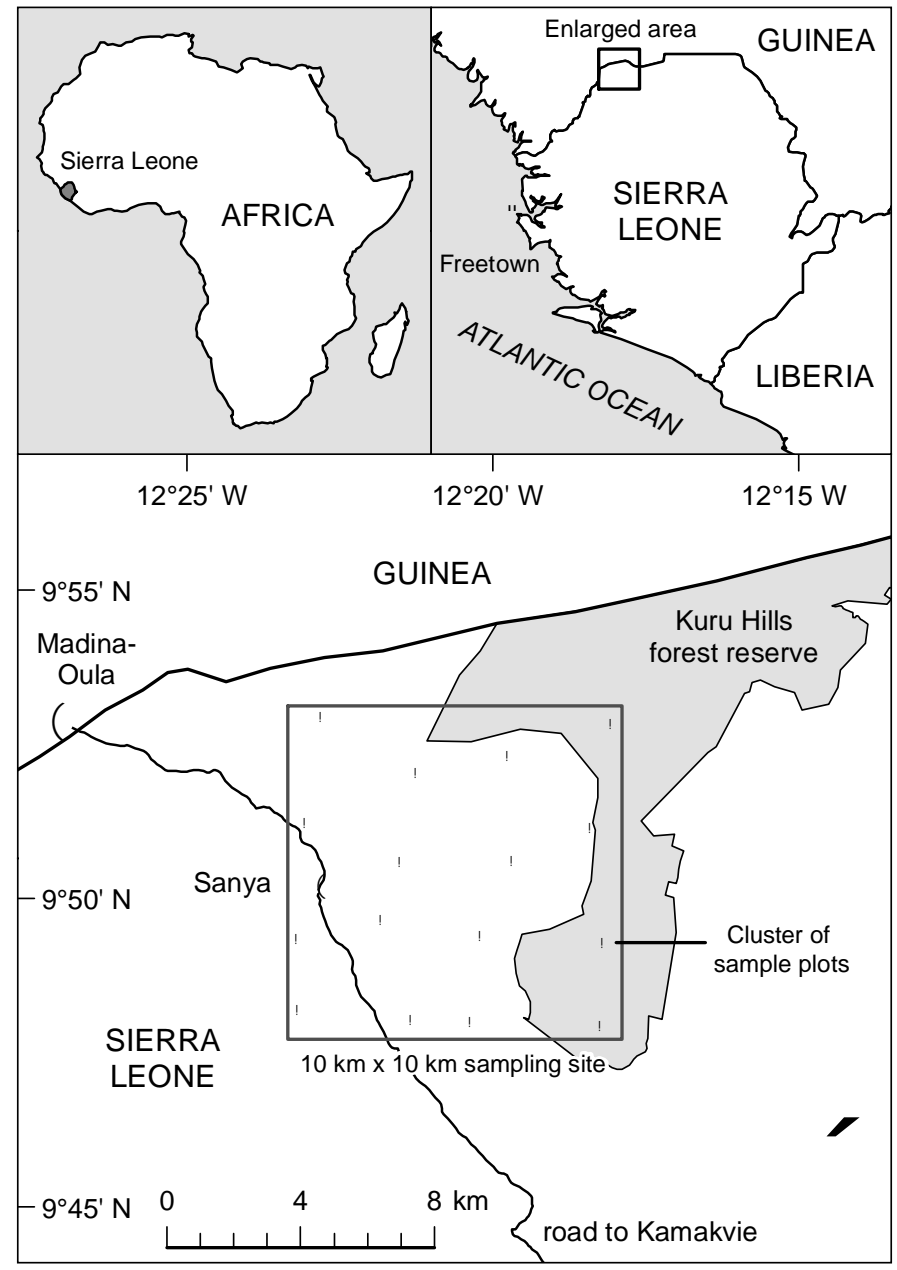

Figure 1. Study area and field plots with the boundaries of the Kuru Hills Forest Reserve in Northern Sierra Leone. 

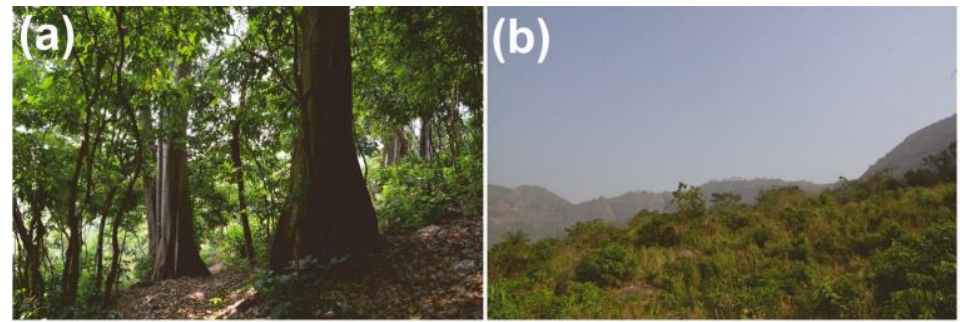

(d)

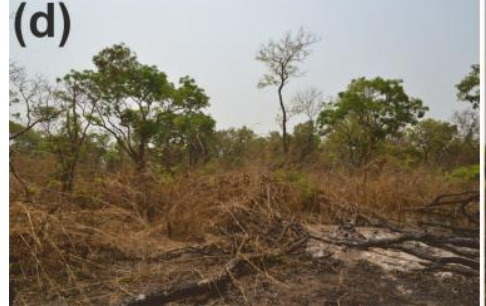

(e)

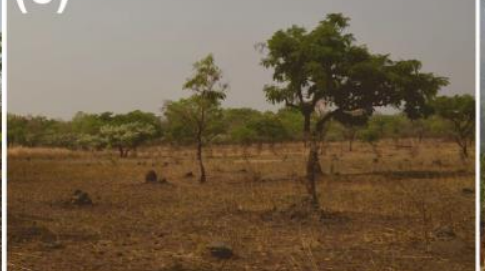

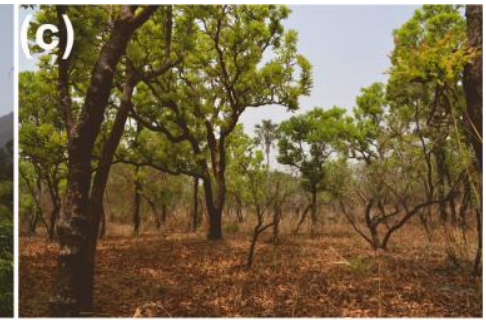

(f)

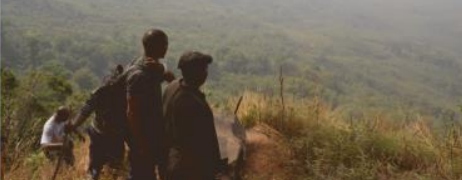

Figure 2. (a) Forest on the slopes of the Kuru Hills, (b) bushland with the Kuru Hills in the background, (c) woodland in the plateau, (d) wooded and partly burned grassland, (e) cropland and (f) Kuru Hills rising from the plateau covered by bushland. Note the smoke from the wildfires in the air. Photos by P. Pellikka, 2014. 


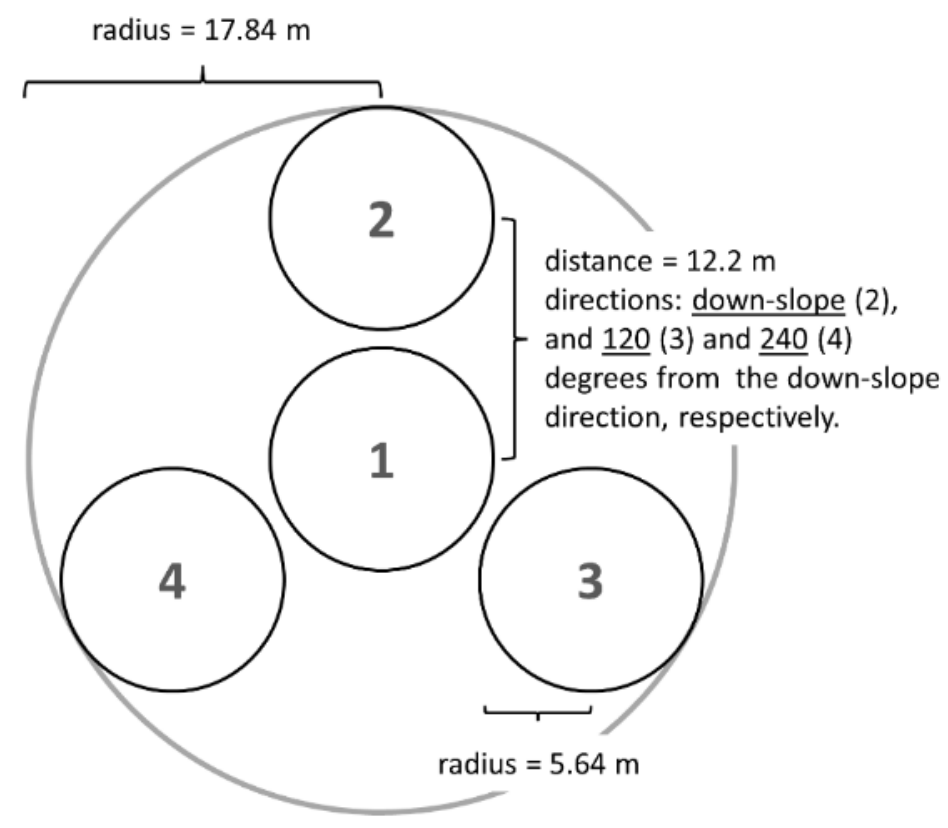

Figure 3. Sample plot design with 0.1 ha plot and four 0.01 ha sub-plots. 


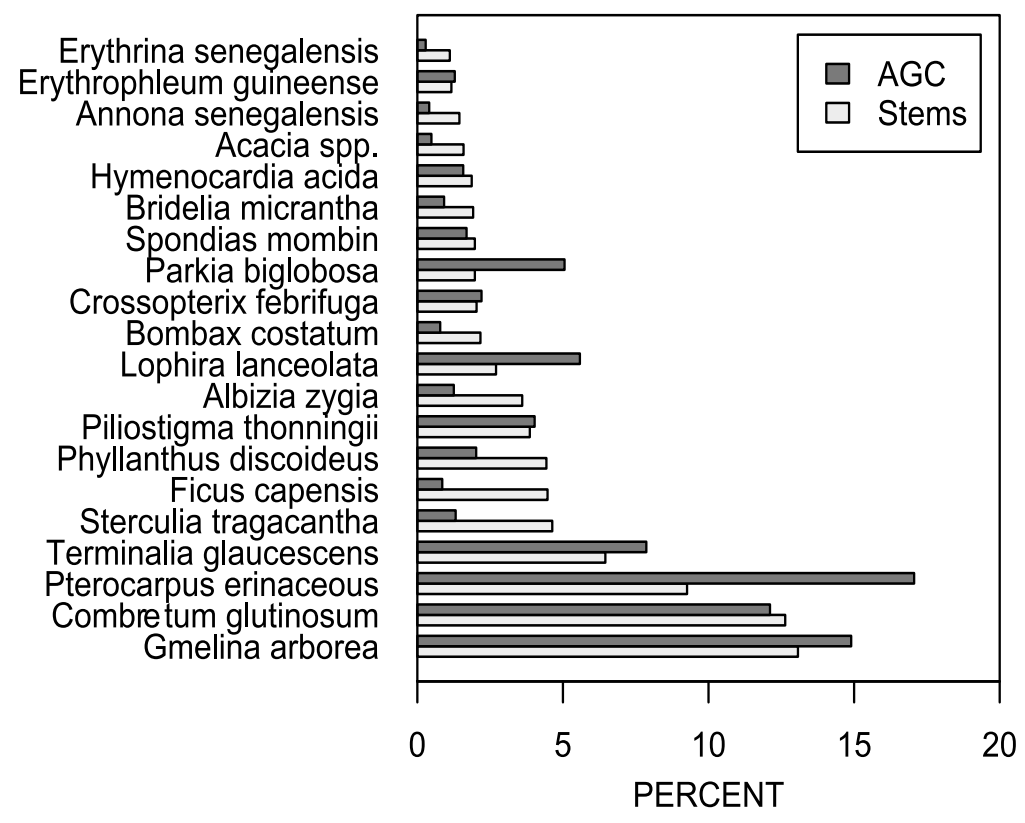

Figure 4. The relative abundance (\%) of the most common tree species in the landscape in terms of AGC and number of stems. 

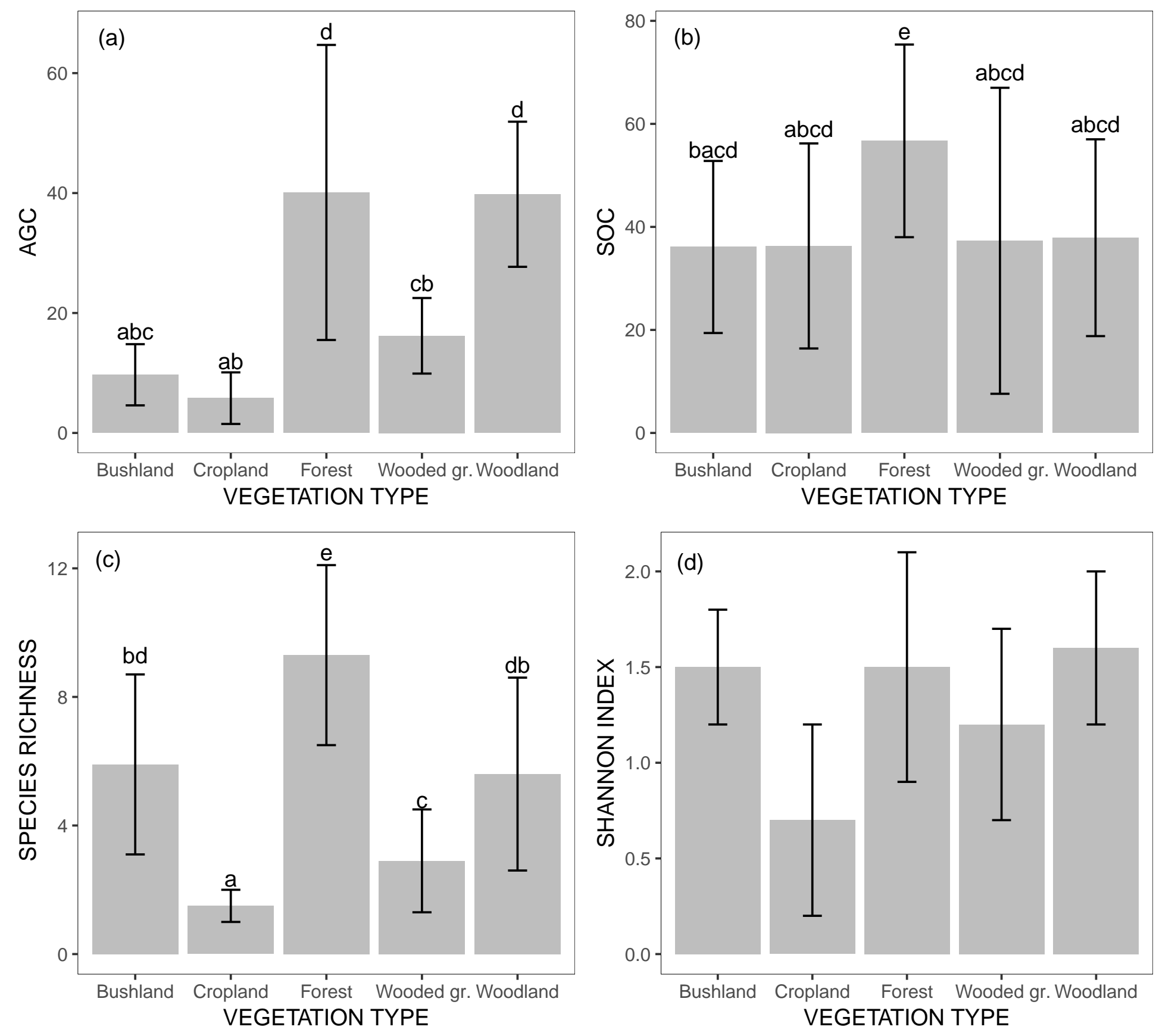

Figure 5. Comparison of (a) AGC, (b) SOC stock in the top 0-20 cm depth, (c) tree species richness and (d) Shannon index between vegetation types. Wooded gr. = wooded grassland. 

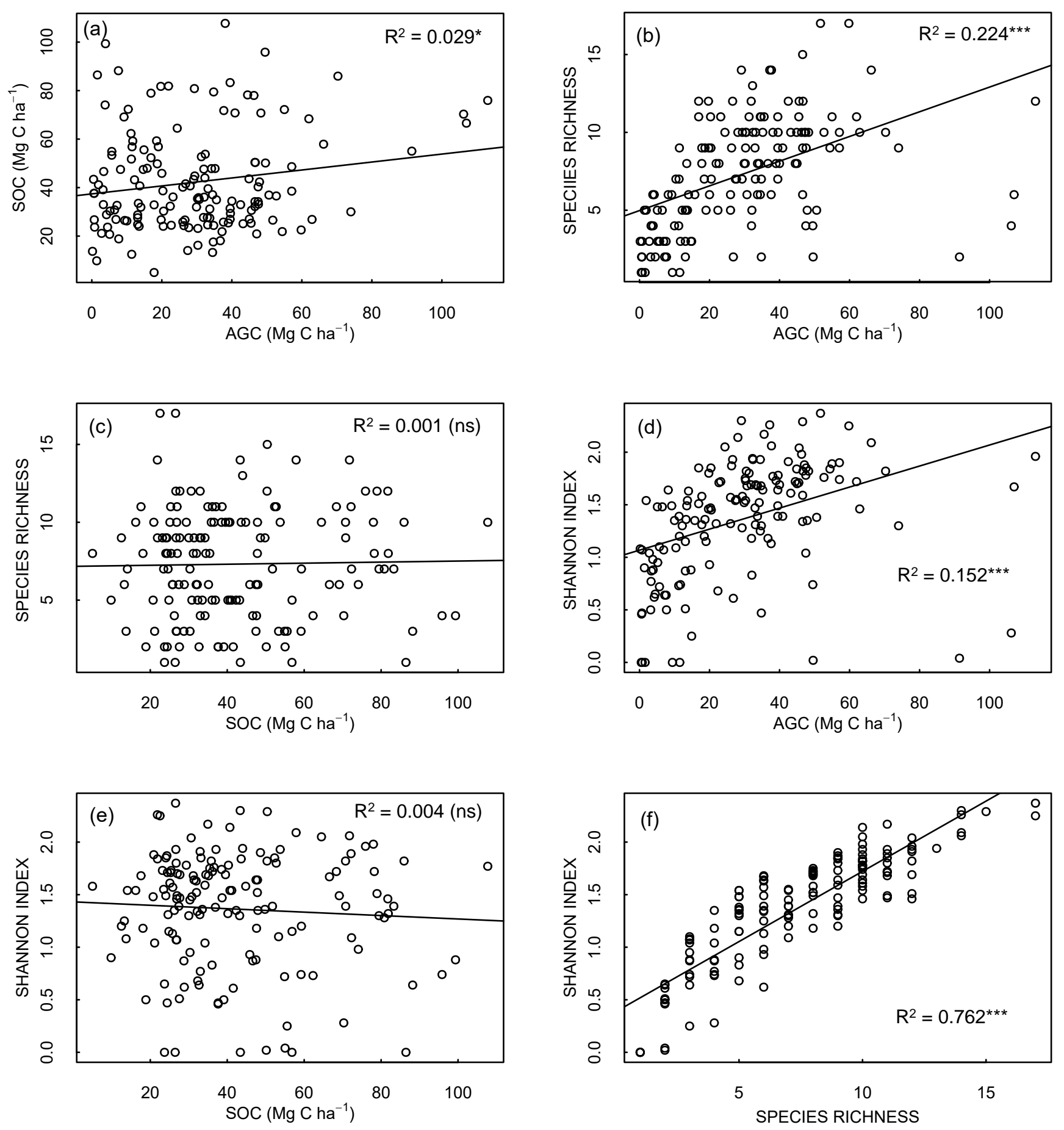

Figure 6. The relationships of carbon stock and tree species diversity variables: (a) AGC vs. SOC,

(b) tree species richness vs. AGC, (c) tree species richness vs. SOC, (d) Shannon index vs. AGC,

(e) Shannon index vs. SOC and (f) species richness vs. Shannon index. 
Table 1. Vegetation types used for grouping the field plots.

\begin{tabular}{lll}
\hline Type & Description & Number of \\
& & plots \\
\hline Forest & A continuous stand of trees with crowns interlocking. & 24 \\
Woodland & An open stand of trees with canopy cover $\geq 40 \%$. The & 66 \\
& field layer dominated by grasses. & \\
Bushland & A mix of trees and shrubs with a canopy cover $\geq 40 \%$. & 13 \\
Wooded & Land covered with grasses and other herbs with & 29 \\
grassland & woody vegetation covering 10-40 \% of the ground. & \\
Cropland & Cultivated land with annual or perennial crops. & 28 \\
\hline
\end{tabular}


Table 2. Variation in AGC, SOC at $0-20 \mathrm{~cm}$ depth, species richness and Shannon index at landscape-level $(n=160)$.

\begin{tabular}{lcccc}
\hline Variables & Min & Max & Mean & SD \\
& & & & \\
\hline AGC $\left(\mathrm{Mg} \mathrm{C} \mathrm{ha-1}^{-1}\right)$ & 0.2 & 113.0 & 29.4 & 21.3 \\
SOC $\left(\mathrm{Mg} \mathrm{C} \mathrm{ha-1}^{-1}\right)$ & 4.9 & 107.2 & 42.2 & 20.6 \\
Species richness & 1 & 17 & 7 & 4 \\
Shannon index & 0 & 2.4 & 1.6 & 0.6 \\
\hline
\end{tabular}


Table 3. Relative abundance (\%) of stems, AGC and species in DBH classes.

\begin{tabular}{llll}
\hline DBH & Stems (\%) & AGC (\%) & Species (\%) \\
\hline $4-10$ & 63.0 & 1.1 & 17.1 \\
$10.1-20$ & 23.0 & 18.8 & 21.2 \\
$20.1-30$ & 8.2 & 24.9 & 19.2 \\
$30.1-40$ & 3.6 & 21.9 & 13.5 \\
$40.1-50$ & 1.4 & 13.8 & 13.9 \\
$50.1-60$ & 0.5 & 7.8 & 7.8 \\
$>60$ & 0.4 & 11.7 & 7.3 \\
\hline
\end{tabular}


Table 4. Relative abundance (\%) of the large trees $(\mathrm{DBH}>60 \mathrm{~cm})$ in terms of stems and AGC in different vegetation types.

\begin{tabular}{lll}
\hline Vegetation type & Stems (\%) & AGC (\%) \\
\hline Forest & 0.32 & 12.3 \\
Bushland & 0.13 & 16.6 \\
Woodland & 0.38 & 8.5 \\
Wooded grassland & 0.07 & 5.6 \\
Cropland & 0.27 & 9.0 \\
\hline
\end{tabular}

